\title{
Hospitalized older adult: predictors of functional decline*
}

\author{
João Paulo de Almeida Tavares ${ }^{1}$ \\ (1D) https://orcid.org/0000-0003-3027-7978 \\ Lisa Alexandra Nogueira Veiga Nunes² \\ (D) https://orcid.org/0000-0001-9701-027X \\ Joana Catarina Gonçalves Grácio ${ }^{3}$ \\ (D) https://orcid.org/0000-0002-0882-2717
}

Objective: to identify the predictors of functional decline in hospitalized individuals aged 70 or over, between: baseline and discharge; discharge and follow-up, and baseline and three-month follow-up. Method: a prospective cohort study conducted in internal medicine services. A questionnaire was applied (clinical and demographic variables, and predictors of functional decline) at three moments. The predictors were determined using the binary logistic regression model. Results: the sample included 101 patients, 53.3\% female, mean age of $82.47 \pm 6.57$ years old. The predictors that most contributed to decline in hospitalization were the following: previous hospitalization $(\mathrm{OR}=1.8)$, access to social support ( $O R=4.86)$, cognitive deficit $(O R=6.35)$, mechanical restraint $(O R=7.82)$, and not having a partner $(O R=4.34)$. Age $(O R=1.18)$ and medical diagnosis $(O R=0.10)$ were the predictors between discharge and follow-up. Being older, delirium during hospitalization $(\mathrm{OR}=5.92)$, and presenting risk of functional decline $(O R=5.53)$ were predictors of decline between the baseline and follow-up. Conclusion: the most relevant predictors were age, previous hospitalization, cognitive deficit, restraint, social support, not having a partner, and delirium. Carrying out interventions aimed at minimizing the impact of these predictors can be an important contribution in the prevention of functional decline.

Descriptors: Aged; Health of the Elderly; Nursing; Hospitalization; Logistic Models; Functional Decline.

\section{How to cite this article}

Tavares JPA, Nunes LANV, Grácio JCG. Hospitalized older adult: predictors of functional decline. Rev. Latino-Am. Enfermagem. 2021;29:e3399. [Access DOI: http://dx.doi.org/10.1590/1518-8345.3612.3399.

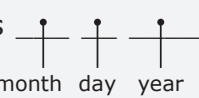
; Available in: 


\section{Introduction}

Hospitalization results in functional decline (FD) for the older adults (OAs) due to the interaction between the changes in primary aging, the disease, and the hospital practices ${ }^{(1-2)}$. FD is characterized by the inability to engage in necessary or desirable activities in daily life. FD is not only linked to the clinical condition that led to the hospitalization; as such, its recovery is not automatic after the resolution of the medical problem(3).

The literature highlights multiple factors that put hospitalized people at risk of FD. Delirium or the presence of cognitive deficit, low performance in activities of daily living at baseline, advanced age, sensory deficits, depression, and multimorbidity are associated with increased risk of FD and decreased likelihood of improvement after hospitalization(4-7). Additionally, previous hospitalizations ${ }^{(5)}$, the iatrogenic effects of the treatment ${ }^{(8)}$, the absence of an informal support network ${ }^{(9)}$, and the number of falls in the last year(3) $^{(3)}$ also accentuate FD. The factors related to the hospital practices that reinforce low mobility and bed rest ${ }^{(4,10-14)}$, polymedication, the use of psychotropic drugs, direct and/or indirect restraint, malnutrition, and the use of medical devices (e.g., use of vesical catheterization) $)^{(3,15-18)}$ are also associated with FD. The hospital environment and politics play an equally significant role(19-20).

The patients who are unable to recover after the hospitalization episode may maintain the declining trajectory ${ }^{(3,21-22)}$, so the predictors of FD must be identified early in order to take preventive measures ${ }^{(2)}$. Many times, these predictors reflect the sociocultural system of the health services and of the development of current care. In Portugal, as far as the authors' knowledge is concerned, there are no studies that have analyzed the predictors of functional decline in hospitalized older adults aged 70 or over. This study had as its objective to identify the predictors of functional decline in hospitalized people aged 70 years old or older, between: baseline and discharge; discharge and follow-up, and baseline and three-month follow-up.

\section{Method}

A prospective cohort study carried out in internal medicine services in a central public university hospital of the central region of Portugal. Two hospitalization units for men and two for women were included. Each service has 33 beds, with a mean monthly occupation of $100 \%$. The research was approved by the Ethics Commission of the hospital (opinion No. 065-14) and the data were collected after clarification of the study and acquisition of the consent term.

The sample was of the consecutive convenience type. The inclusion criteria were the following: individuals aged $\geq 70$ years old with the ability to understand and interpret the questions of the questionnaire (informed consent to the patients or, if not possible, having an informal caregiver who answered the questionnaire). The exclusion criteria were as follows: older adults transferred from the intensive care unit, older adults with terminal or neurodegenerative disease, totally dependent at baseline (maximum score in the Katz Index), and hospitalizations of less than 48 hours.

Calculation of the sample was conducted and, for a moderate effect size (0.5), level of significance (a) of 0.05 and power $(\beta)$ of 0.8 , the number of 102 participants was obtained. The sample included 117 patients in an initial phase, with intention to compensate for possible drop-outs and, at discharge time, it consisted of 101 participants. Due to this fact, the power of the test for the sample obtained was calculated (post-hoc), resulting in a power of 0.8 .

In order to identify the largest number of predictors of FD, a questionnaire was carried out which included sociodemographic and clinical data, as well as different scales (Table 1 ).

The assessment of the functional capacity was performed with the Katz Index (KI). It is an instrument with six basic activities of daily life (BADL) of dichotomous reply ( $0=$ dependent, $1=$ independent). The older adults and/or caregivers were asked to describe their functional capacity prior to hospitalization (baseline), reporting the last two weeks. The decline in the BADL between baseline and discharge was defined as t0; $\mathrm{t} 1$ corresponded to the decline between discharge and follow-up (FU); and t2 reported the decline between baseline and FU (Figure 1). In this study, FD was defined as any decline in one or more points in the KI between the three moments at which the assessment was conducted.

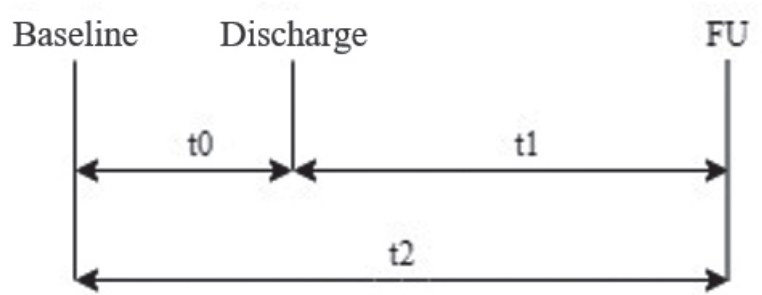

Figure 1 - Moments of the assessment of the functionality of the hospitalized older adults 
Table 1 - Variables, instruments and moments of data collection. Coimbra, Portugal, 2016

\begin{tabular}{|c|c|c|}
\hline Variable & Instrument & Collection moment \\
\hline Age, gender, level of schooling, marital status, family nucleus & Sociodemographic questionnaire & Admission \\
\hline $\begin{array}{l}\text { Admission date, admission diagnosis(es), multimorbidity, number of } \\
\text { previous hospitalizations, hospitalization period, number and type of } \\
\text { medications, and therapeutical attitudes }\end{array}$ & $\begin{array}{l}\text { Clinical questionnaire and Charlson } \\
\text { Comorbidity Index }\end{array}$ & Admission \\
\hline Cognitive decline & Cognitive Decrease Test $(6 \mathrm{CIT})^{(23)}$ & Admission \\
\hline Senses (sight and hearing) & $\begin{array}{l}\text { Question "can you see well?"; "can you hear } \\
\text { well?" }\end{array}$ & Admission \\
\hline Affective state & Single item of the Geriatric Depression Scale ${ }^{(24)}$ & $\begin{array}{l}\text { During hospitalization } \\
\text { ( } 3 \text { to } 5 \text { days after admission) }\end{array}$ \\
\hline Fear of falling & Single item of fear of falling ${ }^{(25)}$ & During hospitalization \\
\hline Falls & Record of falls during hospitalization & Discharge \\
\hline Pain & Numerical Scale or Qualitative Scale & During hospitalization \\
\hline Delirium & Confusion Assessment Method ${ }^{(26)}$ & $\begin{array}{l}\text { Admission and during } \\
\text { hospitalization }\end{array}$ \\
\hline Restraint & Observation grid of physical restriction ${ }^{(27)}$ & During hospitalization \\
\hline Risk of functional decline & ISAR-HP - Portuguese version ${ }^{(28)}$ & Admission \\
\hline Functional capacity of the $\mathrm{OA}$ & Katz Index ${ }^{(29)}$ & $\begin{array}{l}\text { Admission, discharge and } \\
\text { follow-up }\end{array}$ \\
\hline
\end{tabular}

Data collection took place from May to October 2016. In the initial assessment, the patients admitted in the services were analyzed daily in order to identify the ones that presented eligibility criteria. The data were collected by the researchers through: heterofilling of the questionnaire (preferably with the patient or, if not possible, with the informal caregivers, or with the health team: nurses, physicians, and operational assistants), consultation of the clinical diary, of the electronic medical record, and through telephone contact to obtain the followup data. A three-month FU was chosen given that some studies reported that, in this period ( $1^{\text {st }}$ and $3^{\text {rd }}$ months after discharge), a significant number of older adults can recover their functionality ${ }^{(30-31)}$.

In the analysis of the data, techniques of descriptive and inferential statistics were used. In the univariate analysis, the Student's t test was used (when the normality of the distribution was not verified, Mann-Whitney's $U$ test was used), as well as ANOVA (when the normality of the distribution was not verified, Kruskal-Wallis $\mathrm{H}$ test was used), and the chi-square test with Odds Ratio (OR) (when the estimates of the chi-square test were not verified, Fisher's exact test was used).

In the multivariate analysis, the binary logistic regression model was used for the three declines under study ( $\mathrm{t} 0, \mathrm{t} 1$, and $\mathrm{t} 2$ ). The variables to include in the model were selected in accordance with the following: the number of cases (one predictor for every ten cases), $p \leq 0.15$, and predictors with evidence in the literature ${ }^{(32-34)}$. The correlation between the independent variables was analyzed, those with values $\geq 0.75$ being excluded. The conditional backward selection method was used for the selection of the variables with a predictive value. In the statistical treatment of the data, the IBM SPSS 23
(Statistical Package for the Social Sciences) statistical program was used. A $p$-value $<0.05$ was considered statistically significant.

\section{Results}

A total of 117 patients were included, of which the following were excluded: 10 due to death, four due to transfers to other services, one due to absence of baseline, and one for hospitalization of less than 48 hours. The final sample consisted of 101 patients. Approximately half of the sample consists of female older adults $(53.3 \%)$, with a mean age of $82.47 \pm 6.57$ years old and mostly widowed (49\%). More than half presents low schooling (0-2 years) (57.4\%), and only $7.9 \%$ of the sample has seven or more years of study. They live predominantly in their homes or in family homes (83.2\%), and only $17(16.8 \%)$ are institutionalized $(2.95 \pm 2.79$ years $)$. The most prevalent medical admission diagnoses were infectious disease $(42.6 \%)$, cardiovascular disease $(17.8 \%)$, and hydroelectrolytic imbalance (12.9\%). Twenty-five percent of the patients had been hospitalized in the last year, of which $74.29 \%, 13.86 \%$ and $8.57 \%$ were hospitalized once, twice or three times, respectively.

Most of the patients are polymedicated (75.2\%) and have four pathologies; the Charlson Comorbidity Index (CCI) (0-8) presented a median of six (4-7) and the Estimated Relative Risk of Death (ERRD) (0-19.37) was 9.23 (4.4-13.4). More than half of the sample reports not seeing well, $54.4 \%$ does not hear well, and $71.3 \%$ reports weight loss in the last three months. High risk of fall was identified in $48 \%$ of the patients, $58.5 \%$ of the patients reported being afraid of falling, and four patients fell during their stay in the hospital. Thirty-two point three 
percent $(32.3 \%)$ have a high risk of pressure injury. Most of the patients $(68 \%)$ reported feeling sad or depressed frequently, $58 \%$ had no cognitive deficit, nine patients presented delirium in the first 48 hours, and eight patients developed delirium during hospitalization. The mean length of hospitalization was $9.97 \pm 7.02$ days.

Predictors of functional decline: At t0, in the univariate analysis of the sociodemographic and clinical variables, it was observed that the older adults who declined were significantly more likely to be: male $(O R=2.5)$, 2.7 years old older, without a partner $(\mathrm{OR}=3.7)$, and with previous social support; with more hospitalizations within the last year, with a higher risk of falls, higher risk of pressure injury $(\mathrm{OR}=3.5)$, cognitive deficit, depression ( $\mathrm{OR}=2.9)$, delirium at admission, and restraint during hospitalization $(\mathrm{OR}=6.5)$. Assessed at admission, delirium only occurred in patients with decline, reason why it represents an isolated predictive variable (it does not enter into the logistic regression model, for presenting 0 cases in the patients without decline).

The regression model was statistically significant $\left(x^{2}(5)=38.85, p<0.01\right)$. Having been hospitalized in the previous year $(\mathrm{OR}=1.8)$, having access to social support prior to hospitalization ( $\mathrm{OR}=4.86)$, presenting cognitive deficit $(O R=6.35)$, having been subjected to mechanical restraint $(\mathrm{OR}=7.82)$, and not having a partner $(\mathrm{OR}=4.34)$ are significant predictors of decline during hospitalization. The model explains $52.3 \%$ of the variance of functional decline and correctly classified $82.1 \%$ of the cases (relation between the true values and those predicted by the model). It was observed that the ROC curve of the predictive model for t0 presented an area of $0.87(p \leq 0.01)(95 \% \mathrm{CI}$ : 0.79-0.95), with a standard error of 0.04 .

At $\mathrm{t} 1$, it was observed that the older adults who declined are likely to be nearly five years old older (median). Decline is also dependent on the medical admission diagnosis, for which there is a positive association between the absence of decline and the diagnosis of infectious disease $(n=39$; adjusted residue $=3.4$ ) and between the presence of decline and the diagnosis of lung disease $(n=2$; adjusted residue=2.4).

For the clinical variables, the OAs with decline at $\mathrm{t} 1$ were more frequently hospitalized in the last year and have higher CCI and ERRD. The place of residence of the OAs, three months after discharge, is dependent on the decline that occurs between discharge and follow-up, with a positive association between decline at $\mathrm{t} 1$ and institutionalization at follow-up ( $n=9$; adjusted residue=2.7). The same is true between the absence of decline and home stay $(n=51$; adjusted residue $=2.6$ ). It was observed that the decline is dependent on the ISAR-HP score, so the patients classified as at risk (ISAR-HP $\geq 2$ ) are 11.73 times more likely to have FD in the three months after discharge.

Table 2 - Sociodemographic and clinical characteristics of the OAs according to functional decline at t0. Coimbra, Portugal, 2016

\begin{tabular}{|c|c|c|c|c|}
\hline \multirow{2}{*}{ Clinical characteristics } & \multirow{2}{*}{$\begin{array}{l}\text { Patients without } \\
\text { decline }(n=74)\end{array}$} & \multirow{2}{*}{$\begin{array}{c}\text { Patients with } \\
\text { decline }(n=27)\end{array}$} & \multirow{2}{*}{ p/OR } & \multirow{2}{*}{$\frac{\log ^{\dagger} \text { regression }}{\text { p/OR }}$} \\
\hline & & & & \\
\hline Age $\left(M^{\ddagger} \pm S D^{\S}\right)$ & $81.0(6.08)$ & $83.69(6.77)$ & $0.04^{* *}$ & $0.76 / 0.98$ \\
\hline Male $(\%)$ & $20(42.6)$ & $27(57.4)$ & $0.03^{+t} / 2.5$ & $0.71 / 1.32$ \\
\hline Without a partner (\%) & $37(68.5)$ & $17(37)$ & $0.01^{+t} / 3.7$ & $0.02 / 4.34$ \\
\hline With social support (t0) (\%) & $5(12.5)$ & $14(31.8)$ & $0.04^{t \dagger} / 0.31$ & $0.04 / 4.86$ \\
\hline Hospitalizations in the last year (Median, $1^{\text {st }}$ and $3^{\text {rd }}$ ) & $0(0-0)$ & $0(0-1)$ & $<0.01^{\text {ㅁ }}$ & $0.03 / 1.80$ \\
\hline Psychoactive drugs & $20(43.5)$ & $34(61.8)$ & $0.07^{\dagger \dagger}$ & $0.13 / 2.77$ \\
\hline Does not see well $(\%)$ & $21(45.7)$ & $35(63.6)$ & $0.07^{t \dagger}$ & $0.32 / 0.51$ \\
\hline Does not hear well (\%) & $13(28.3)$ & $23(41.8)$ & $0.16^{\dagger+}$ & $0.50 / 0.56$ \\
\hline Fear of falling $(\%)$ & $20(47.6)$ & $35(67.3)$ & $0.05^{t \dagger}$ & $0.78 / 1.27$ \\
\hline High risk of falls (\%) & $20(44.4)$ & $28(50.9)$ & $0.01^{\mathrm{t \dagger}}$ & $0.23 / 4.34$ \\
\hline High risk of $\mathrm{PI}(\%)$ & $8(18.2)$ & $24(43.6)$ & $<0.01^{\dagger+} / 3.5$ & $0.46 / 1.84$ \\
\hline Cognitive decline (\%) & $12(26.1)$ & $30(55.6)$ & $<0.01^{\dagger+} / 3.5$ & $<0.01 / 6.35$ \\
\hline Depression & $25(55.6)$ & $43(78.6)$ & $0.02^{t+}$ & $0.97 / 0.96$ \\
\hline Delirium at admission (\%) & - & $9(16.4)$ & $<0.01^{\dagger+} / 2$ & - \\
\hline Delirium during hospitalization (\%) & $2(4.8)$ & $8(15.1)$ & $0.18^{t \dagger}$ & $0.46 / 2.84$ \\
\hline Restraint (\%) & $6(14.3)$ & $27(51.9)$ & $<0.01^{\dagger+} / 6.5$ & $<0.01 / 7.82$ \\
\hline $\mathrm{CCF}^{\mathrm{T}}\left(\mathrm{Me}, 1^{\text {st }}\right.$ and $\left.3^{\text {rd }} \mathrm{Q}\right)$ & $\begin{array}{c}0.5 \\
(0.22-0.56)\end{array}$ & $\begin{array}{c}0.47 \\
(0.36-0.63)\end{array}$ & $0.30^{\ddagger \ddagger}$ & $0.69 / 1.91$ \\
\hline Risk of functional decline (\%) & $30(65.2)$ & $47(85.5)$ & $0.02^{t+} / 3.1$ & $0.84 / 1.22$ \\
\hline
\end{tabular}

${ }^{*} \mathrm{OR}=$ Odds Ratio; ${ }^{\mathrm{L}} \mathrm{Log}=$ Logistic; ${ }^{\ddagger} \mathrm{M}=$ Mean; ${ }^{5} \mathrm{SD}=$ Standard deviation; "PI = Pressure injury; ${ }^{9} \mathrm{CCF}=$ Care Centered on Functionality; ${ }^{* *}$ Student's $t$ test; ${ }^{++}$Chi-square test; ${ }^{\neq \neq}$Mann-Whitney's U test 
The regression model was statistically significant $\left(X^{2}(2)=28.05, p<0.01\right)$ and showed that age $(O R=1.18)$ and diagnosis $(\mathrm{OR}=0.10)$ are significant predictors of functional decline between discharge and follow-up. The model explains $35.3 \%$ of the functional decline variance and correctly classified $73.3 \%$ of the cases. It was observed that the ROC curve of the predictive model for t1 presented an area of 0.83 ( $p \leq 0.01)(95 \%$ CI: $0.74-$ 0.92 ) with a standard error of 0.05 .

At $t 2$, it was verified that the patients who declined were the oldest (approximately five years old older compared to the patients who did not decline), those who were more frequently hospitalized in the last year, those who had CCI and ERRD with higher scores, and those who had longer hospitalizations (two more days - median). They were also those who reported feeling sad or depressed more frequently and had delirium episodes during hospitalization. It was observed that functional decline at $\mathrm{t} 2$ is dependent on the risk assessment by ISAR-HP, and that the older adults at risk are 10.72 times more likely to have functional decline.

Through the logistic regression (Table 4 ), whose model is statistically significant $\left(x^{2}(3)=25.55, p<0.01\right)$, it was verified that being older, presenting delirium during hospitalization ( $O R=5.92)$, and presenting risk of decline, identified through ISAR-HP $(\mathrm{OR}=5.53)$, are the variables that most predict decline in this period. The model explains $31.8 \%$ of the functional decline variance and correctly classified $71.6 \%$ of the cases. It was observed that the ROC curve of the predictive model for $\mathrm{t} 2$ presented an area of $0.78(p \leq 0.01)(95 \% \mathrm{CI}: 0.69-0.87)$ with a standard error of 0.05 .

Table 3 - Sociodemographic and clinical characteristics of the OAs according to functional decline at t1. Coimbra, Portugal, 2016

\begin{tabular}{|c|c|c|c|c|}
\hline \multirow{2}{*}{ Clinical characteristics } & \multirow{2}{*}{$\begin{array}{l}\text { Patients without } \\
\text { decline }(n=74)\end{array}$} & \multirow{2}{*}{$\begin{array}{l}\text { Patients with } \\
\text { decline }(n=27)\end{array}$} & \multirow{2}{*}{$p / O R^{*}$} & \multirow{2}{*}{$\frac{\log ^{\dagger} \text { regression }}{\text { p/OR }}$} \\
\hline & & & & \\
\hline Age (Median, $1^{\text {st }}$ and $3^{\text {rd }} \mathrm{Q}$ ) & $81(76-87)$ & $86(83-89)$ & $<0.01^{\S}$ & $<0.01 / 1.18$ \\
\hline $\begin{array}{l}\text { Admission diagnosis (\%) } \\
\text { Infectious disease }\end{array}$ & $39(38.6)$ & $4(4)$ & $<0.01^{\|}$ & $<0.01 / 0.10$ \\
\hline Number of medications (Median, $1^{\text {st }}$ and $3^{\text {rd }} \mathrm{Q}$ ) & $6.5(3.75-10)$ & $8(6-11)$ & $0.11^{\S}$ & $0.48 / 1.05$ \\
\hline $\begin{array}{l}\text { Hospitalizations in the last year (Median, } 1^{\text {st }} \\
\text { and } 3^{\text {rd }} Q \text { ) }\end{array}$ & $0(0-1)$ & $1(0-1)$ & $0.03^{\S}$ & $0.077 / 0.92$ \\
\hline $\mathrm{CCl}^{\ddagger}\left(\right.$ Median, $1^{\text {st }}$ and $\left.3^{\text {rd }} \mathrm{Q}\right)$ & $4(4-7)$ & $6(5-8)$ & $0.01^{\S}$ & $0.21 / 1.2$ \\
\hline Does not hear well (\%) & $23(31.1)$ & $13(48.1)$ & $0.11 \pi$ & $0.92 / 1.08$ \\
\hline Weight loss (\%) & $49(66.2)$ & $23(85.2)$ & $0.06 \pi$ & $0.39 / 1.84$ \\
\hline Delirium during hospitalization (\%) & $5(7.2)$ & $5(19.2)$ & $0.13^{\|}$ & $0.16 / 3.62$ \\
\hline Cognitive decline (\%) & $28(37.8)$ & $14(53.8)$ & $0.15^{\pi}$ & $0.44 / 1.593$ \\
\hline Risk of functional decline (\%) & $51(68.9)$ & $26(96.3)$ & $<0.01 \pi / 11.7$ & $0.14 / 5.29$ \\
\hline
\end{tabular}

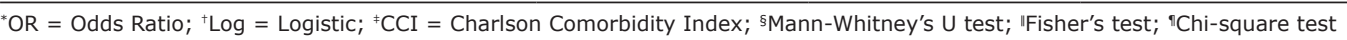

Table 4 - Sociodemographic and clinical characteristics of the OAs according to functional decline at t2. Coimbra, Portugal, 2016

\begin{tabular}{|c|c|c|c|c|}
\hline \multirow{2}{*}{ Clinical characteristics } & \multirow{2}{*}{$\begin{array}{l}\text { Patients without } \\
\text { decline }(n=74)\end{array}$} & \multirow{2}{*}{$\begin{array}{c}\text { Patients with } \\
\text { decline }(n=27)\end{array}$} & \multirow{2}{*}{$p / \mathrm{OR}^{*}$} & \multirow{2}{*}{$\frac{\log ^{\dagger} \text { regression }}{\text { p/OR }}$} \\
\hline & & & & \\
\hline Age $\left(\mathrm{M}^{\ddagger} \pm \mathrm{SD} \mathrm{D}^{\S}\right)$ & $80.34(6.22)$ & $85.77(5.77)$ & $0.00^{* *}$ & $0.04 / 1.10$ \\
\hline With social support (t0) (\%) & $9(17.3)$ & $10(31.3)$ & $0.14^{\dagger \dagger}$ & $0.43 / 1.65$ \\
\hline Hospitalizations in the last year (\%) & $0(0-1)$ & $0(0-1)$ & $0.09 \neq$ & $0.99 / 0.99$ \\
\hline $\mathrm{CCl}^{\prime \prime}\left(\mathrm{Me}, 1^{\text {st }}\right.$ and $\left.3^{\text {rd }} \mathrm{Q}\right)$ & $5(4-7)$ & $6(4-7)$ & $0.04^{\ddagger}$ & $0.29 / 1.14$ \\
\hline $\mathrm{ERRD}^{\pi}\left(M e, 1^{\text {st }}\right.$ and $\left.3^{\text {rd }} \mathrm{Q}\right)$ & $6.38(4.4-13.37)$ & $9.23(6.38-13.37)$ & $0.05^{\ddagger \neq}$ & $0.87 / 1.02$ \\
\hline Does not hear well $(\%)$ & $18(29.5)$ & $18(45.0)$ & $0.11^{\dagger \dagger}$ & $0.74 / 0.83$ \\
\hline Cognitive decline $(\%)$ & $21(34.5)$ & $21(53.8)$ & $0.06^{++}$ & $0.62 / 1.35$ \\
\hline Depression & $35(58)$ & $33(82.5)$ & $0.02^{+\dagger} / 0.3$ & $0.14 / 2.35$ \\
\hline Delirium during hospitalization (\%) & $2(3.6)$ & $8(20.5)$ & $0.01^{\S \S}$ & $0.06 / 5.9$ \\
\hline Restraint (\%) & $15(26.8)$ & $18(47.4)$ & $0.13^{+\dagger}$ & $0.88 / 1.02$ \\
\hline Length of hospitalization (Median, $1^{\text {st }}$ and $3^{\text {rd }} Q$ ) & $7(5-10)$ & $9(6-17.5)$ & $0.05^{\ddagger \ddagger}$ & $0.97 / 0.99$ \\
\hline Risk of functional decline (\%) & $39(63.9)$ & $38(95.0)$ & $<0.01^{\dagger t / 10.72}$ & $0.04 / 5.53$ \\
\hline
\end{tabular}

${ }^{*} \mathrm{OR}=$ Odds Ratio; ${ }^{\dagger} \mathrm{Log}=$ Logistic; ${ }^{\ddagger} \mathrm{M}=$ Median; ${ }^{\circledR} \mathrm{SD}=$ Standard deviation; "CCI = Charlson Comorbidity Index; ${ }^{\mathrm{E}} \mathrm{ERRD}=$ Estimated Relative Risk of Death; ${ }^{* *}$ Student's $t$ test; ${ }^{++}$Chi-square test; ${ }^{* \neq}$ Mann-Whitney's $U$ test; ${ }^{\S}$ Fisher's test 


\section{Discussion}

This study sought to analyze the variables that condition FD at three moments. It was observed that the demographic and clinical variables have a more significant impact between baseline and discharge, compared to other periods under analysis ( $\mathrm{t} 1$ and $\mathrm{t} 2$ ). It was identified that the "advanced age", "hospitalization in the last year", "delirium", and presenting "risk of decline" variables were transversal predictors to these moments. These data had already been identified in a systematic review study(5), reinforcing the importance of incorporating in the initial assessment of the patients issues related to previous hospitalizations, to delirium, and to the assessment of the risk of functional decline.

Older adults with functional decline at to had more geriatric conditions (sight problems, risk of PI, cognitive changes, depression, delirium), did not have a partner, were previously hospitalized, and were restrained during hospitalization. These conditions are associated with worse health outcomes, namely FD during hospitalization ${ }^{(3,7)}$. This study is eloquent in the predictive value of delirium and of FD. It was observed that delirium at admission affects the functional trajectory between baseline and discharge and, on the other hand, delirium diagnosed during hospitalization affects the functional trajectory between discharge and follow-up and between baseline and follow-up. This result confirms that delirium is related to a worse functional recovery, as well as to longer hospitalization periods(35-37). The assessment of delirium is not a systematic practice in Portugal and its recognition among nurses is $\operatorname{low}^{(38)}$. Likewise, the performance of a cognitive follow-up at the time of admission, which is also infrequent, must be considered as the first intervention in its prevention. However, the sample of patients with delirium is small (test power), which limits the accuracy of the results. On the other hand, the exclusion criteria may have discarded patients with more predisposing factors, therefore with a higher risk of developing delirium. Additionally, the assessment of delirium at admission occurred at a single moment and in the morning period. Future studies should consider its assessment at various times of the day and characterize it as to its onset and subtype.

The influence of previous hospitalizations is a relevant data and has already been identified in another study ${ }^{(3)}$. The data on unscheduled hospitalization (occurring within a period of 30 days after discharge) report a rate of $4.7 \%$, being more significant in the age group of older adults ${ }^{(39)}$. Considering that $41.6 \%$ of the individuals do not recover their baseline, we may be facing a continuous cascade of functional loss between each hospitalization.
Another significant predictor was restraint ${ }^{(40-41)}$. The use of restraints is worsened during hospitalization and is linked to other predictors ${ }^{(41)}$, such as cognitive deficit, a predisposing factor for delirium which, in turn, can predetermine the use of restraints. This hospital practice is more frequent in older adults, who are already vulnerable to the adverse events resulting from restraints (e.g., incontinence, isolation, pressure injury, infection, delirium, and death due to aspiration) $)^{(41-42)}$. The use of alternative measures to the restraints must be considered in the context of Portuguese care. However, it will only be possible to reduce/eliminate the use of restraints by intervening in the causes, namely in the lack of human and material resources, in the insufficient training of the professionals in the management of behavioral and psychological symptoms ${ }^{(37)}$.

Older adults have a higher risk of functional decline at $t 1$ and $t 2$. The reduction in the functional reserve and in the resistance to balance-disturbing events can be an explanation. In this study, the mean age was 83 years old, which can represent a reduced functional reserve and deficits in multiple physiological systems, encompassing aspects such as decreased muscle mass, strength, resistance and balance, with lower activity capacity. Advanced age increases by $25 \%$ the prevalence of the frailty syndrome in individuals aged 80 and over ${ }^{(43)}$. Faced with a stressful event, such as hospitalization, frail older adults are at risk of severe deterioration in their physical and psychological wellbeing(44-45), which can contribute to a more pronounced decline in these patients.

It was observed that the diagnosis is a predictor of functional decline after hospital discharge, in line with other studies $(3,7,46)$. This research analyzed the pathologies by two groups (infection and non-infection diagnoses). The group of pathologies classified as "noninfection" includes a wide range of diseases, reason why the analysis by groups of pathologies alone would be relevant to understand their predictive value in decline. The complexity of many of these pathologies, such as oncological disease, heart failure, chronic kidney injury, and chronic obstructive pulmonary disease, can result in greater functional limitations for the older adults, not only during hospitalization but also on their return home. The management of more complex signs, symptoms, and therapeutic regimens after discharge can increase the risk of adverse events, side effects and drug iatrogenesis. All these factors can contribute to the more pronounced functional decline between discharge and follow-up. These data reinforce the importance of the admission diagnosis in the decline after discharge, so that programs for the management of chronic disease and an articulation with resources in the community 
can be understood as strategies capable of mitigating functional decline in this group of patients with diagnoses associated to more chronic events.

Regarding the limitations of the study, we cite the following: the small sample size $(n=101)$, which limits the power of the statistical tests to detect relevant associations in the analysis of the predictors of functional decline; the self-report of functional capacity, referring that the patients and/or caregivers can under- or overestimate these values. A physical performance measure would allow obtaining more accurate data of functionality. As a third limitation, the non-inclusion of variables such as the number of falls in the last year, mobility of the patients in the hospital, socioeconomic status, and medication introduced during hospitalization. The inclusion of these variables could improve the variance explained by the models. Future studies should consider them in data collection. Although the missings of the study are not very significant, it is suggested to attribute these data using statistical algorithms (e.g., single linear regression method), in order to increase the number of cases in the logistic regression. The fourth limitation consisted in not assessing functional capacity at admission. Future studies should consider this assessment in order to determine the impact of acute diseases on pre-hospitalization. This data would be relevant to clarify the effect of the disease on the functional trajectory. Although the impact of an acute disease may be significant, the functional trajectory can be independent of $i^{(30)}$, with hospitalization playing a very significant role ${ }^{(15)}$. The fifth limitation is that the assessment during hospitalization took place at a single moment. Extending this assessment to more moments could allow for the identification of a greater number of predictors. Finally, these results must be generalized with caution, taking into account the specific context (internal medicine services) in a university hospital. Multicenter studies would be decisive to determine the predictors of functional decline among hospitalized older adults in Portugal.

This study allows evidencing the factors that most contributed to functional decline in the older adults hospitalized in internal medicine services, with the following standing out: age, hospitalization in the last year, cognitive deficit, restraint, and delirium. Some of these predictors stem from the health-disease process; however, others can be associated with the hospital practice.

\section{Conclusion}

This study showed that the transversal predictors to FD were as follows: advanced age, hospitalization in the last year, delirium, and having an assessment of risk of decline. During hospitalization, the most significant predictors of FD were the following: previous hospitalization, access to social support, cognitive deficit, mechanical restraint, and not having a partner. Between discharge and follow-up, the main predictors of FD were age and medical diagnosis. Finally, between baseline and follow-up, advanced age, delirium, and the risk of FD were the most relevant predictors. Implementing targeted interventions with specific guidelines for these predictors, especially those associated with the hospital practice, such as the use of restraints and delirium, will certainly contribute to preventing FD in hospitalized older adults.

\section{References}

1. van Vliet M, Huisman M, Deeg DJH. Decreasing Hospital Length of Stay: Effects on Daily Functioning in Older Adults. J Am Geriatr Soc. [Internet]. 2017 Jun [cited Mar 23, 2018];65(6):1214-21. Available from: http:// doi.wiley.com/10.1111/jgs.14767

2. Lafrenière $S$, Folch N, Dubois $S$, Bédard L, Ducharme F. Strategies Used by Older Patients to Prevent Functional Decline During Hospitalization. Clin Nurs Res. [Internet]. 2017 Feb 25 [cited Mar 23, 2018];26(1):626. Available from: http://journals.sagepub.com/ doi/10.1177/1054773815601392

3. Palese A, Gonella S, Moreale R, Guarnier A, Barelli P, Zambiasi $P$, et al. Hospital-acquired functional decline in older patients cared for in acute medical wards and predictors: Findings from a multicentre longitudinal study. Geriatr Nurs (Minneap). [Internet]. 2016 May [cited Oct 10, 2017];37(3):192-9. Available from: https://linkinghub. elsevier.com/retrieve/pii/S0197457216000458

4. Boltz M, Capezuti E, Shabbat N, Hall K. Going home better not worse: Older adults' views on physical function during hospitalization. Int J Nurs Pract. [Internet]. 2010 Jul 22 [cited Mar 23, 2018];16(4):381-8. Available from: http://doi.wiley.com/10.1111/j.1440172X.2010.01855.X

5. Hoogerduijn JG, Schuurmans MJ, Duijnstee MS, de Rooij SE, Grypdonck MF. A systematic review of predictors and screening instruments to identify older hospitalized patients at risk for functional decline. J Clin Nurs. [Internet]. 2007 Jan [cited May 15, 2017];16(1):46-57. Available from: http://doi.wiley.com/10.1111/j.13652702.2006.01579.x

6. Jonkman NH, Del Panta V, Hoekstra T, Colpo $M$, van Schoor NM, Bandinelli $S$, et al. Predicting Trajectories of Functional Decline in 60- to 70-YearOld People. Gerontology. [Internet]. 2018 [cited Aug 23, 2019];64(3):212-21. Available from: https://www. karger.com/DOI/10.1159/000485135 
7. Basic D, Ní Chróinín D, Conforti D, Shanley C. Predictors on admission of functional decline among older patients hospitalised for acute care: A prospective observational study. Australas ] Ageing. [Internet]. 2017 Dec 1 [cited Feb 7, 2019];36(4):E57-63. Available from: https://doi. org/10.1111/ajag.12458

8. Hoogerduijn JG, Grobbee DE, Schuurmans MJ. Prevention of functional decline in older hospitalized patients: Nurses should play a key role in safe and adequate care. Int J Nurs Pract. [Internet]. 2014 Feb 1 [cited Mar 23, 2018];20(1):106-13. Available from: http://dx.doi.org/10.1111/ijn.12134

9. Lowthian JA, Straney LD, Brand CA, Barker A, Smit $\mathrm{PV}$, Newnham $\mathrm{H}$, et al. Predicting functional decline in older emergency patients - the Safe Elderly Emergency Discharge (SEED) project. Age Ageing. [Internet]. 2017 Mar 1 [cited Oct 10, 2017];46(2):219-25. Available from: https://doi.org/10.1093/ageing/afw210

10. Resnick B, Boltz M. Optimizing Function and Physical Activity in Hospitalized Older Adults to Prevent Functional Decline and Falls. Clin Geriatr Med. [Internet]. 2019 May [cited Mar 11, 2019];35(2):237-51. Available from: https://linkinghub.elsevier.com/retrieve/pii/ S0749069019300047

11. Brown CJ, Redden DT, Flood KL, Allman RM. The Underrecognized Epidemic of Low Mobility During Hospitalization of Older Adults. J Am Geriatr Soc. [Internet]. 2009 Sep [cited Mar 11, 2019];57(9):16605. Available from: http://doi.wiley.com/10.1111/j.15325415.2009.02393.x

12. Zisberg A, Syn-Hershko A. Factors related to the mobility of hospitalized older adults: A prospective cohort study. Geriatr Nurs (Minneap). [Internet]. 2016 Mar 7 [cited Mar 23, 2018];37(2):96-100. Available from: http://dx.doi.org/10.1016/j.gerinurse.2015.10.012

13. Calero-García MJ, Ortega AR, Navarro E, Calero MD. Relationship between hospitalization and functional and cognitive impairment in hospitalized older adults patients. Aging Ment Health. [Internet]. 2017 Nov 2 [cited Mar 11, 2019];21(11):1164-70. Available from: https://www. tandfonline.com/doi/full/10.1080/13607863.2016.1220 917

14. Dermody G, Kovach CR. Nurses' Experience With and Perception of Barriers to Promoting Mobility in Hospitalized Older Adults: A Descriptive Study. J Gerontol Nurs. [Internet]. 2017 Nov 1 [cited Mar 10, 2019];43(11):229. Available from: http://search.ebscohost.com/login.as px direct $=$ true $\& \mathrm{db}=\mathrm{cmedm} \& \mathrm{AN}=28556874 \&$ site $=$ eho st-live

15. Covinsky KE, Pierluissi E, Johnston CB. HospitalizationAssociated Disability. JAMA. [Internet]. 2011 Oct 26 [cited Mar 23, 2018];306(16):1782-93. Available from: http:// jama.jamanetwork.com/article.aspx?doi=10.1001/ jama.2011.1556

16. Zisberg A, Gary S, Gur-Yaish N, Admi H, Shadmi E. In-Hospital Use of Continence Aids and New-Onset Urinary Incontinence in Adults Aged 70 and Older. J Am Geriatr Soc. [Internet]. 2011 Jun [cited Mar 23, 2018];59(6):1099-104. Available from: http://doi.wiley. com/10.1111/j.1532-5415.2011.03413.x

17. Vetrano $D L$, Rizzuto $D$, Calderón-Larrañaga $A$, Onder G, Welmer AK, Bernabei R, et al. Trajectories of functional decline in older adults with neuropsychiatric and cardiovascular multimorbidity: A Swedish cohort study. PLOS Med. [Internet]. 2018 Mar 6 [cited Aug 23, 2019];15(3):e1002503. Available from: https://www. ncbi.nlm.nih.gov/pubmed/29509768

18. Menezes KVRS, Auger C, Barbosa JFS, Gomes CS, Menezes WRS, Guerra RO. Trajectories and Predictors of Functional Capacity Decline in Older Adults From a Brazilian Northeastern Hospital. J Geriatr Phys Ther. [Internet]. 2019 Dec [cited Jan 23, 2020]. Available from: https://journals.Iww.com/jgpt/Fulltext/publishahead/ Trajectories_and_Predictors_of_Functional_ Capacity.99658.aspx

19. Dermody G, Kovach CR. Barriers to Promoting Mobility in Hospitalized Older Adults. Res Gerontol Nurs. [Internet]. 2018 Jan 1 [cited Aug 23, 2019];11(1):1727. Available from: http://www.healio.com/doiresolver? doi $=10.3928 / 19404921-20171023-01$

20. Tavares J, Grácio J, Nunes L. Assessment of hospital environments and policies: seeking an age-friendly hospital. Rev Bras Geriatr Gerontol. [Internet]. 2017 Apr [cited Mar 23, 2018];20(2):254-8. Available from: http:// www.scielo.br/scielo.php?script=sci_arttext\&pid=S180998232017000200254\&lng=en\&tIng=en

21. Huang HT, Chang CM, Liu LF, Lin HS, Chen CH. Trajectories and predictors of functional decline of hospitalised older patients. J Clin Nurs. [Internet]. 2013 May [cited Mar 10, 2019];22(9-10):1322-31. Available from: http://doi.wiley.com/10.1111/jocn.12055

22. Tavares J, Grácio J, Nunes L. Hospitalized older adults: functional trajectory in Portuguese hospital. Rev Enferm Ref. [Internet]. 2018 Oct 9 [cited Aug 23, 2019];IV Série(18):19-28. Available from: https://rr.esenfc.pt/rr/ index. php? module $=$ rr\&target $=$ publicationDetails\&pesqu isa $=\& i d$ artigo $=2902 \&$ id_revista $=24 \& i d \_$edicao $=138$ 23. Apóstolo JLA, Paiva DDS, Silva RCG, Santos EJF, Schultz TJ. Adaptation and validation into Portuguese language of the six-item cognitive impairment test (6CIT). Aging Ment Health. [Internet]. 2018 Sep 2 [cited Mar 23, 2018];22(9):1190-5. Available from: https:// www.tandfonline.com/doi/full/10.1080/13607863.2017. 1348473 
24. Maboney J, Drinka TJK, Abler R, Gunter-Hunt G, Matthews C, Gravenstein S, et al. Screening for Depression: Single Question versus GDS. J Am Geriatr Soc. [Internet]. 1994 Sep [cited Mar 23, 2018];42(9):1006-8. Available from: http://doi.wiley.com/10.1111/j.1532-5415.1994. tb06597.x

25. Resnick B, Wells C, Galik E, Holtzman L, Zhu S, Gamertsfelder E, et al. Feasibility and Efficacy of Function-Focused Care for Orthopedic Trauma Patients. J Trauma Nurs. [Internet]. 2016 [cited Mar 23, 2018];23(3):144-55. Available from: http://content. wkhealth.com/linkback/openurl?sid=WKPTLP:landingpa ge\&an=00043860-201605000-00007

26. Sampaio F, Sequeira C. Tradução e validação do Confusion Assessment Method para a população portuguesa. Rev Enferm Ref. [Internet]. 2013 Mar 29 [Acesso 23 mar 2018];III Série(no 9):125-34. Disponível em: https://www.esenfc.pt/rr/index.php?module=rr\&tar get $=$ publicationDetails\&pesquisa $=\& i d \_$artigo $=2361 \& i d$ revista $=9 \&$ id_edicao $=51$

27. Faria H, Paiva A, Marques P. A restrição física da mobilidade - estudo sobre os aspetos ligados à sua utilização com fins terapêuticos. Rev Enferm Ref. [Internet]. 2012 Mar 31 [cited 23 mar 2018];III Série(no 6):7-16. Disponível em: http://www.esenfc.pt/rr/index. php ? module $=$ rr\&target $=$ publicationDetails $\&$ pesquisa $=\&$ id_artigo $=2274 \&$ id_revista $=9$ \&id_edicao $=41$

28. Tavares J, Grácio J, Nunes L. Predictive validity of the Identification of Seniors at Risk - Hospitalized Patient tool for identifying functional decline. Rev Enferm Ref. [Internet]. 2017 Dec 18 [cited Aug 23, 2019];IV Série(No15):145-54. Available from: https://rr.esenfc.pt/ rr/index. php ?module $=r$ \&target $=$ publicationDetails\&pesq uisa $=$ \&id_artigo $=2751$ \&id_revista $=24 \& i d \_$edicao $=117$

29. Simões AL, Ferreira PL, Dourado M. Medição da autonomia em atividades da vida diária. Port J Public Health. [Internet]. 2018 [Acesso 23 ago 2019];36(1):915. Disponível em: https://www.karger.com/ DOI/10.1159/000492139

30. Boyd CM, Landefeld CS, Counsell SR, Palmer RM, Fortinsky RH, Kresevic D, et al. Recovery of Activities of Daily Living in Older Adults After Hospitalization for Acute Medical Illness. J Am Geriatr Soc. [Internet]. 2008 Dec [cited Mar 11, 2019];56(12):2171-9. Available from: http://doi.wiley.com/10.1111/j.1532-5415.2008.02023.x 31. Chen CC, Wang C, Huang G. Functional Trajectory 6 Months Posthospitalization. Nurs Res. [Internet]. 2008 Mar [cited Mar 11, 2019];57(2):93-100. Available from: http://www.ncbi.nlm.nih.gov/pubmed/18347480

32. Hoogerduijn JG, Buurman BM, Korevaar JC, Grobbee DE, de Rooij SE, Schuurmans MJ. The prediction of functional decline in older hospitalised patients. Age Ageing. [Internet]. 2012 May [cited Mar 11,
2019];41(3):381-7. Available from: https://academic. oup.com/ageing/article-lookup/doi/10.1093/ageing/ afs015

33. Hoogerduijn J, De Rooij S, Grobbee D, Schuurmans $M$. Predicting functional decline in older cardiac surgery patients: Validation the ISAR-HP identification of seniors at risk - hospitalized patients. Eur Geriatr Med. [Internet]. 2012 Sep [cited Mar 11, 2019];3:S9. Available from: http:// dx.doi.org/10.1016/j.eurger.2012.07.389\%5Cnhttp:// ovidsp.ovid.com/ovidweb.cgi?T=JS\&PAGE $=$ reference\&D $=$ emed10\&NEWS $=$ N\&AN $=70878426$

34. Hoogerduijn JG, Schuurmans MJ, Korevaar JC, Buurman BM, de Rooij SE. Identification of older hospitalised patients at risk for functional decline, a study to compare the predictive values of three screening instruments. J Clin Nurs. [Internet]. 2010 May [cited Mar 1, 2019];19(9-10):1219-25. Available from: http://doi. wiley.com/10.1111/j.1365-2702.2009.03035.x

35. Kleinpell R. Supporting Independence in Hospitalized Elders in Acute Care. Crit Care Nurs Clin North Am. [Internet]. 2007 Sep [cited Feb 7, 2019];19(3):247-52. Available from: https://linkinghub.elsevier.com/retrieve/ pii/S0899588507000342

36. D'Onofrio A, Büla C, Rubli E, Butrogno F, Morin D. Functional trajectories of older patients admitted to an Acute Care Unit for Elders. Int J Older People Nurs. [Internet]. 2018 Mar [cited Feb 7, 2019];13(1):e12164. Available from: http://doi. wiley.com/10.1111/opn.12164 37. Haley MN, Casey $P$, Kane RY, Dārzinš $P$, Lawler K. Delirium management: Let's get physical? A systematic review and meta-analysis. Australas ] Ageing. [Internet]. 2019 Dec 22 [cited 2020 Feb 17];38(4):231-41. Available from: https://doi.org/10.1111/ajag.12636

38. Silva RCG, Silva AAP, Marques PAO. Analysis of a health team's records and nurses' perceptions concerning signs and symptoms of delirium. Rev. Latino-Am. Enfermagem. [Internet]. 2011 Feb [cited Feb 7, 2019];19(1):81-9. Available from: http://www. scielo.br/scielo.php?script=sci_arttext\&pid=S0104$11692011000100012 \&$ Ing =en\&tlng=en

39. Sousa-Pinto B, Gomes AR, Oliveira A, Ivo C, Costa G, Ramos J, et al. Hospital readmissions in Portugal over the last decade. Acta Med Port. 2013;26(6):711-20.

40. Lachance C, Wright MD. Avoidance of Physical Restraint Use among Hospitalized Older Adults: A Review of Clinical Effectiveness and Guidelines. [Internet]. Ottawa: Canadian Agency for Drugs and Technologies in Health; 2019 [cited Aug 27, 2019]. Available from: https://www.ncbi.nlm.nih.gov/books/NBK545889/

41. Chou MY, Hsu YH, Wang YC, Chu CS, Liao MC, Liang CK, et al. The Adverse Effects of Physical Restraint Use among Older Adult Patients Admitted to the Internal Medicine Wards: A Hospital-Based Retrospective Cohort 
Study. J Nutr Health Aging. [Internet]. 2020 Feb 9 [cited Feb 17, 2020];24(2):160-5. Available from: https://doi. org/10.1007/s12603-019-1306-7

42. Dahlke SA, Hunter KF, Negrin K. Nursing practice with hospitalised older people: Safety and harm. Int J Older People Nurs. [Internet]. 2019 Mar [cited Feb 17, 2020];14(1):e12220. Available from: http://doi.wiley. com/10.1111/opn.12220

43. Fried LP, Tangen CM, Walston J, Newman AB, Hirsch C, Gottdiener J, et al. Frailty in Older Adults: Evidence for a Phenotype. Journals Gerontol Ser A Biol Sci Med Sci. [Internet]. 2001 Mar 1 [cited Feb 7, 2019];56(3):M146-57. Available from: https://academic. oup.com/biomedgerontology/article-lookup/doi/10.1093/ gerona/56.3.M146

44. Apóstolo J, Cooke R, Bobrowicz-Campos E, Santana S, Marcucci M, Cano A, et al. Predicting risk and outcomes for frail older adults: an umbrella review of frailty screening tools. JBI Database Syst Rev Implement Reports. [Internet]. 2017 Apr [cited Aug 23, 2019];15(4):1154208. Available from: https://www.ncbi.nlm.nih.gov/ pubmed/28398987

45. Chong E, Ho E, Baldevarona-Llego J, Chan M, Wu L, Tay L, et al. Frailty in Hospitalized Older Adults: Comparing Different Frailty Measures in Predicting Shortand Long-term Patient Outcomes. J Am Med Dir Assoc. [Internet]. 2018 May [cited Feb 7, 2019];19(5):450457.e3. Available from: http://www.sciencedirect.com/ science/article/pii/S1525861017305807

46. Fimognari FL, Pierantozzi A, De Alfieri $W$, Salani B, Zuccaro SM, Arone A, et al. The Severity of Acute Illness and Functional Trajectories in Hospitalized Older Medical Patients. Journals Gerontol Ser A Biol Sci Med Sci. [Internet]. 2017 Jan [cited Aug 23, 2019];72(1):1028. Available from: https://academic.oup.com/ biomedgerontology/article-lookup/doi/10.1093/gerona/ glw096
Corresponding author:

João Paulo de Almeida Tavares

E-mail: joaoptavares@ua.pt

(D) https://orcid.org/0000-0003-3027-7978
Received: Aug 23rd 2019

Accepted: Jul 16 th 2020

Associate editor:

Rosalina Aparecida Partezani Rodrigues

Copyright @ 2021 Revista Latino-Americana de Enfermagem This is an Open Access article distributed under the terms of the Creative Commons (CC BY).

This license lets others distribute, remix, tweak, and build upon your work, even commercially, as long as they credit you for the original creation. This is the most accommodating of licenses offered. Recommended for maximum dissemination and use of licensed materials. 